\title{
On Reaction Of Subcutaneous Connective Tissue Mast Cell In Various Fixatives
}

\author{
By \\ Yoshinori Takeda \\ Department of Anatomy, Yamaguchi University, School of Medicine, \\ Ube, Japan \\ (Director: Prof. G. Ji m bo)
}

As for mast cell, its study is traced back to the theory by E h r lich (1877) who, discovering in connective tissue of vertebrate, granules stained deep in basic aniline solution, expressed his view that this cell was the same one with that plasma cell discovered by Waldey er (1875) and then after-wards, changing his first view, announced another that this cell, the granules being special, was of different kind from plasma cell and congested at the part, where local nutrition is advanced, such as chronic inflammation, congestion and tumor, and that, this cell being transformed because of the hypertrophy of connective tissue cells, has been called mast cell.

Since many studies on this cell have been expressed and the information has been extended, but as for the interesting various problems such as the process of genesis of blood mast cell and tissue mast cell, the correlation between them, mother-cell to generate tissue mast cell, or the motion and phagocytose of the cell and other inter. esing problems.

The views by many scholars are different and not definite.

Since Jorpes, Holmgren and Wilander (1937-1939) advanced heparin theory-the granules of this cell consist of heparin various fixative methods have been studied by many workers but they are almost identical each, most of them being the method to fix in $10 \%$ basic lead acetate solution, and to stain in $1 \%$ toluidin blue (modification of Holmgren's method) or to fix in absolute alcohol or in formalin.

But these fixative methods also are not yet perfect in the study of tissue mast cell, and there seem to be still much left to be studied, what reaction tissue mast cells assume to various fixative agents are 
studied first.

\section{Material and Methods}

In this study 15 kinds of fixatives were used, the names and densities of which are as follows:

Is r a bin and acrinol solution (each $1 / 50 \mathrm{M}$ ); $50 \%$ alcohol solution; $4 \%$ basic lead acetate aqueous solution; absolute alcohol solution; $10 \%$ and $4 \%$ formalin solutions; neutral formalin solution; Z e n k e r's solution; $\mathrm{Or}$ th's solution ; $5 \%$ potassium dichromate solution; saturated picric acid solution; osmic acid solution; $M$ ü $11 \mathrm{e}$ r's solution.

As experimental material, the subcutaneous connective tissue of 10-15 gr white mouse is used because mast cell of mouse is comparatively insoluble to water ( $\mathrm{Mi}$ u ra, 1932) and chiefly used back subcutaneous connective tissue in which tissue mast cells are contained most in quantity.

To begin with after cutting off carotid artery, white mouse was anesthetized with choloroform and at once pinching off the back subcutaneous connective tissue at a moderate size, and it was spread quickly on the slide glass and was fixed immediately in the fixatives for 24 hour's and was stained for certain hours in $1 \%$ toluidin blue with much care, then was destained with $70 \%$ alcohol.

After dehydration, metachromasia by staining decreases a little but in order to preserve the preparation longer, it was enclosed in canada balsam through xylene.

Further, the comparative study of the tissue mast cell of mesentery spread preparation with the preparation of cut-off back subcutaneous tissue was made.

\section{Results}

(1) $1 / 20 \mathrm{M}$ israbin aqueous solutions

The experimental materials are divided into two kinds as follows :

(a) Microscopical examination of section which stained in $1 \%$ toluidin blue aqueous solution is made.

(b) Microscopical examination of section which is without being stained is made immediately after dehydration.

As for one stained with toluidine blue, the cell body didn't dissolve and the granules of the cell, too, didn't deliver and disperse and the outline of the cell is very clear and distinct and its granules 
stained deep black and brown and various granule of all sizes could be observed and the relation to the nucleus was very clear and distinct.

As for one, which was not stained with toluidin blue, like the former, the cell body didn't dissolve, and its granules didn't deliver and disperse, so not only the outline of the cell was very clear and distinct, but also its granules were able to be stained deep red and brown with israbin and assume the various granular of sizes and the relation to its nucleus was clear and distinct.

The contrast to the circumjacent connective tissue fibre and other cell is clear and distinct.

Comparing the one stained with toluidin blue with the other stained not with toluidin blue, the latter seems to be cleared esp. as for the granules, the one stained with toluidine blue is coarser and its granules seem to be alone and chemically combined easily and closely with this cytoplasmatic granules which are produced by heparin.

As for this cell, its preparation does not decrease in metachromasia even after the lapse of one month.

(2) $50 \%$ alcohol solution in which israbin at the rate of $1 / 50 \mathrm{M}$.

As in the case of (1) the cell body didn't dissolve and its cytoplasmatic granules didn't deliver and disperse, so the outline of the cell is very clear and distinct, and the granules stained black and brown, but its granules, alcohol being intermixed, stained a little lighter than in the case of (1).

The condition of the granules can be observed to be the granular of all sizes and to be clear and distinct and its relation to the nucleus is clear.

The contrast to the circumferencial connective tissue fibre and the other cells being stained light is not so clear as in the case of (1).

As for this cell, the preparation didn't decrease in metachromasia after the lapse of one month.

(3) $1 / 20 \mathrm{M}$ acrinol aqueous solution.

The cell body didn't dissolve and its cytoplasmatic granules didn't deliver and disperse so the outline of the cell was clear and distinct and were stained green and brown.

The granular condition was observed to be green and brown and to be of all sizes and its relation to the nucleus are clear and distinct, but in some of them the cell body is filled with granules, and so the 
relation of the granules to the nucleus is obscure, but the circumferential connective tissue and other cells stained yellow and brown, and the contrast is clear and distinct.

As for this cell, the preparation didn't decrease in its metachromacsia after the lapse of one month.

(4) $5 \%$ alcohol solution in which acrinol is soluted at the rate of $1 / 50 \mathrm{M}$.

The cell body didn't dissolve and cytoplasmatic granules didn't deliver and disperse, so the outline of granules is clear and distinct.

The granules stained green and brown with acrinol and the granular condition are of all sizes and observed to be very clear and the relation to its nucleus was very clear and distinct, but compared with israbin the granule seems to be a little condensed.

The circumferential connective tissue stained light green and yellow, and the cell is difficult to be stained, so the tissue mast cell seems to close up in light brown and yellow.

As for this cell, the preparation didn't decrease in its metachromasia after the lapse of one month.

(5) $4 \%$ basic lead acetate aqueous solution.

Experimental materials were prepared as follows:

The mast cells which were given watering after fixing and the other mast cells which were stained with $1 \%$ toluidin blue solution after dehydration without giving watering, and partly those stained in $60 \%$ alcohol solution in which toluidin blue is solved at the rate of $1 \%$.

As for the ones given watering and the others not given watering, nearly the same result was observed that the outline of the cell was clear in general, but, in part, the cell body dissolved and damaged and the granules delivered and dispersed, so some of cell bodies were observed to be obseure in the outline.

The granules stained deep red-purple and the metachromasia is distinct and clear and covers the whole cell body. The granular condition is in part clear, but for the most part it is not clear and as for the relation to the nucleus, some are clear but most of them are obscure. (In Holmgren's illustration, it is also not clear.)

Circumferential connective tissue fibre and other cells stained blue and its contrast is clear and distinct.

As for one which was stained with $60 \%$ alcohol solution in which toluidin blue is solved at the rate of $1 \%$, the cell body fused and its outline is obscure and its granules, for the most part, delibered and dispersed, but its contrast to the nucleus stained light red-purple is 
rather clear. Circumferential connective tissue fibre and other cells stained light blue and the contrast is not so clear and distinct as in the $1 \%$ toluidin blue solution staining.

(6) Absolute alcohol solution.

Most of them assume an oval and condensed form. The cell body, in part, diffuse and the outline of the cell lacks in clearness and some granules disperse.

Its granules stained thickly red-purple and its metachromasia is distinct and most parts of the nucleus are covered with granules but some not covered with them stain light purple and there being rather clear.

Circumferential connective tissue fibre and other cell stained cell stained clear blue and their contrast is clear and distinct.

Furthermore, when examined closely through the microscope circumferential tissue fibre and other cell condenced to a certain definite direction (maybe, to the direction from where alcohol infringe) and so the protoplasm and karyoplasm of this cell were pushed to another directions and seems to be condensed thickly.

As for this cell, after the lapse of one month, the preparation already were decolourized in part and its metachromasia decreased.

(7) $10 \%$ formalin solution.

The cell body scarcely dissolved and damaged itself and the outline of cell body is clear. Most of granules scarcely dispersed but some granules of the circumferential parts have a turn to disperse from the cell body and others, in part, can be found to be disperse.

Granules assume the various and clear granular condition of all sizes and nucleus, for the most part, stained light purple and the relation between the protoplasm and the nucleus is very clear.

The circumferential connective tissue fibre and other cells stained light blue and distinct, and the contrast is clear and distinct.

As for the tissue mast cell, its preparation, after the lapse of one month, does not change in its staining and more shows the distinct metachromasia.

(8) $4 \%$ formalin solution

As in $10 \%$ formalin solution the cell can be stainable is this solu. tion and its metachromasia is very distinct, but the cell body dissolves and is damaged, and its granules disperse and the outline of the cell body is obscure. 
Granules have a turn to dissolve and disperse not only in their circumferential parts but in their center.

And nucleus is covered with different qualities of basophile cluster of various sizes which seems to be produced by the dissolving and the agglutination of the granules, and its location is not clear, but only in part, can be gussed.

The circumferential tissue fibre and other cells stained lighter than in $10 \%$ formalin solution and the contrast is clear and distinct.

As for this tissue mast cell, in its preparation, after the lapse of cne month, its metachromasy decreases and is decolarized, but still tissue mast cells can be observed.

(9) Neutral formalin solution.

The cell body dissolves and is damaged and its granules deliber and disperse much, and the outline of cell body is obscure and the cell body stains light purple as $4 \%$ formalin solution and its metachromasia is distinct and it stains darker than in $10 \%$ formalin solution. Its granules can be observed to assume the granules condition of red-purple of all sizes and its existence is clear and distinct, too.

The circumferential connective tissue fibre and other cell stain equally light and the contrast is distinct.

As for tissue mast cell, this preparation is not decolorized and does not change in its metachromasia after the lapse of one month.

(10) Z e n ke r's solution.

The fixing power of this solution to tissue mast cell is weak, so only small parts of tissue mast cell can be detected and most of them cannot.

The cell body is much dissolved or is damaged, and so the form of the cell is much irregular, and the outline is obscure and assumes metachromasia of light red. Its nucleus stains light blue a bit, and so even to guess its existence is difficult.

The circumferential connective tissue fibre stains a bit and other cells do not stain, so the contrast is not clear.

As for tissue mast cell, this preparation, as in dichromic acid potassium is so early decolarized.

(11) Mü ll e r's solution.

Tissue mast cell shows the quite different reaction from the one shown in the above-mentioned various fixatives, that is to say, protoplasm stains equally dark red, and its nucleus does not stain at all, 
and nucleus and granules diffuse.

Protoplasm has a turn to dissolve in circumferential parts and in the center, and so the form of the cell is very irregular and the parts corresponding to the nucleus are wider, compared to the preparations by other fixatives, and is round and clear and occupies a large parts of this cell, and so the protoplasm of the cell seems much contracted.

The circumferential connective tissue fibre does not stain but the other parts of the cell stain dark or light blue. Tissue mast cell in this fixative, after the lapse of one month, is decolarized and becomes obscure, but the trace of metachromasia of the cell can be observed only a bit.

(12) O r th's solution.

The form of tissue mast cell generally swells and becomes large contrary to as in the absolute alcohol and the arrangement of the granules becomes irregular or almost diffuse, and gets lost of its irregular form and assumes light red-purple metachromasia.

The existence of nucleus is obscure and it only assumes the form of unhomogenous big mass of somewhat large shape which seems to be produced by the dissolving and the agglutination of granules as in some $4 \%$ formalin solution.

The circumferential connective tissue fibre and other cell body slightly stain light, and the staining is quite in bad condition, and the contrast is distinct a bit.

The tissue mast cell in the preparation is decolorized early and after the lapse of one month, can not be observed.

(13) $5 \%$ potassium dichromate solution.

Tissue mast cell does not show regular form and the circumferential granules of the cell disperse and the outline of the cell is very obscure and the existence of the nucleus is not clear and can not be perceived. Generally the form of the tissue mast cell gets gross and big, and in part dissolves and shows scarcely metachromasia.

Circumferential connective tissue fibre and other cell slightly stain, and the contrast is not so distinct.

The tissue mast cell, in this fixative preparation, is very early decolorized and after the lapse of one month it cannot be perceived.

(14) Saturated picric acid.

Tissue mast cell cannot be stained at all. Circumferential connective tissue fibre stains green and swells much and other cell does not stain. 
(15) $1 \%$ Osmic acid solution.

Tissue mast cell presents a very interesting phenomenon in this solution, i.e. partially it resembles much to that in $M$ ü 11 e r's solution and its form is very irregular and protoplasm shows metachromasia of light red and its nucleus does not stain at all.

Karyoplasm and granule show the dissolved condition, and protoplasm has a turn to dissolve in the circumference and in the center of the cell body and the other small portion of the cell body shows metachromasia of light red and the granules in it can not be observed and some of them has a turn to dissolve in its circumference.

The circumferential connective tissue fibre stains light blue and other cell stains dark blue, and the contrast is not distinct.

Tissue mast cell shows the decolorization early in the preparation and metachromasia disappears.

\section{Discussion}

The interesting phenomenon of metachromasia, at first, has been observed at the same time by Cornil, and Tugen (1857) and Heschel (1875) respectively, and this term was brought forward forth for the first by Ehrlich (1877).

Of all the reactions of acid mucopolysaccharide, metachromasia is most peculiar and this reaction can not be observed of neuteral mucopolysaccharide.

After the extensive study of metachromasia of sulfureted mucopolysaccharide, it has been recognized that its substance is high molecular sulfuric acid ester and is generally shown in the form of $\mathrm{R}-\mathrm{OSO}_{2} \mathrm{H}$, and since then, in order to study the biological meaning of metachromasia construction, various study from the point of histchemistry has been made, that is to say, esp. Jorpes (1937) W il a nder and Hol m g r e n (1937-1939) and soon made research on metachromasia substance which exists in various tissue and observed that the parallelism among a great number of mast cells, the quantity of granules and heparin effect of the substance which destroys tissue, and secured the confirmation of heparin existing in the granules of mast cell and since then came to believe that this very cell is produced by heparin and after Riley and W est (1852) made it clear that the mast cell which has been considered to contain heparin, high-density of histamin, also.

Tissue mast cell being more readily soluble in water, compared 
with other cells, the detection of cell granules makes it necessary to scrutinize fixative solutions used. Namely, the reaction of tissue mast cell to the fivative solutions must be our great concerns.

In making a survey of the reaction of subcutaneous connective tissue to various fixative solutions.

I have taken up and observed the problem of how the cell body dissolves, how the granule delibers and disperses and dyes in the solutions, on the basis of the clearness of the outline of cell body, for when granule substance delibers and disperses, its outline becomes obscure.

As to whether tissue mast cell is soluble in water or not, there has been divergency of views :

W olf (1902), Maximow (1904), Michaelis (1920), by using dogs, cats, and rabbits as to experimental materials, opined that it is soluble in water, while $\mathrm{Unna}$ (1891) and $\mathrm{Nak}$ a sh ima (1928), using the skin and the mesomentum of rats, expressed a different opinion that it is not soluble. Miura, using the various kinds of animals and their organs as experimental materials, concluded that solubility or insolubility of tissue mast cell granules in water differs much according to the difference of the kinds of animals, their organs or their places of organs, and added that in fixing them, if those animals and their organs comparatively insoluble in water are chosen as the material of study, $10 \%$ formalin solution, $\mathrm{Orth}$ solution may be used without hindrance, but that if this method is applied to other animals used as materials of study, some of animals or their organs which are to show a positive reaction sometimes turn into a negative reaction, so in its detection celloidin section has to be used, fixed in pure alcohol.

$\mathrm{Nag}$ a i and $\mathrm{Miura}$ opined that in the case of animals having water-proof mast cell granules, by using frozen section or paraffin section fixed in $10 \%$ formalin solution, he can detect the existence of mast cell, but the detail of granules and nucleus was abscure.

$\mathrm{Nakajo}(1927-1928)$ and Mi u ra (1932 b) opined that in fixing mast cell, if $4 \%$ basic lead acetate solution is used and toluidin blue dyeing is applied to it, it is possible to detect it qualitively and quantitatively - but, as tissue mast cell is instable to water, it is a question whether the detection of the inside of the tissue of the cell is so exact and minute as to be judged quantitatively of the outcome.

Israbin and acrinol solution-both, acrizin system pigments-are chemically combined well with tissue mast cell granules and the 
sediment insoluble in water and alcohol is produced and its deposited reaction is greatly quantitative.

In detecting tissue mast cell granule of each organ of a dog, when tripaflavin used the dissolved image of the cell body and the delibered and dispersed image of the cell granules could be found and a good result could be obtained, $\mathrm{K}$ it a y a $\mathrm{m}$ a reported.

Tissue mast cell granules show each different and interesting phenomenon to israbin and acrinol solutions-each acrizin pigment-and other various fixatives used to various tissues. Namely tissue mast cell granules are comparatively stable and insoluble to formalin and alcohol-the reducing agents-but, on the contrary, instable to the fixations containing the others oxidizing agent or protein sedimenting agent, and the phonomenon how the tissue mast cell body dissolved and granules delibered and dispersed was found.

This is conciding with the experiment of fixing by $\mathrm{Yamada}$ and $\mathrm{I} m$ an is $h$ i.

The reaction of the cell in formalin compared with that in alcohol, formalin is comparatively more stable than alcohol and is stainable deep theoretically but it is difficult to compare each reaction in both fixatives, but in alcohol fixative its protoplasm and nucleus are made to contract remarkably.

Namely, it is observed by the experiments above mentioned that subcutaneous connective tissue mast cell is under various influences to a considerable extent according to the kinds of the fixatives used.

In close study of the dissolving phenomenon of tissue mast cell this cell granules is comparatively insoluble in formalin solution and alcohol solution and rarely its granules deliber and disperse outside the cell, and as for the dissolving phenomenon, first of all its cell membrane is destroyed and its granules more from its central part to its circumference, the granules in its circumference delibering and dispersing, and next the protoplasm dissolve.

This is much soluble in potassium dichromate solution and saturated picric acid solution and in this case the dissolving phenomenon is different much from that above mentioned, i.e. first cell membrane dissolves and granules in the cell body delibers and disperses toward the circumference explosively and afterwards the granules having dispersed and then the cell body dissolves gradually.

Holmgren's and Wilander's (1935) original method being examined it is found that in its quantitative detection metachromasia is given by using toluidin blue solution and the detection is decided 
by the size and the gradation of the color tone of the granules appeared, but I opine, considering the variation of the bulk of granules in fixing them it is improper that the quantitative detection of the granules is decided by the size of the granules.

$\mathrm{H} \mathrm{jelman}(1952)$ points out that fixed in $10 \%$ basic lead acetate solution and stained in $1 \%$ tolutidin blue solution it shows $20-25 \%$ shrinking percentage.

It is improper to adopt the gradation of colour tone as the standard of the judgment, for metachromasia itself changes according to the temperature of the solution, $\mathrm{PH}$ gradation and salt, which has been proved to be so as the result of the close study by $\mathrm{Y} \mathrm{a} \mathrm{m} \mathrm{a} \mathrm{d} \mathrm{a} \mathrm{(1934)}$ $\mathrm{L}$ i s o n (1935) U r a k a mi (1940). Fixed in israbin solution and acrinol solution-both, dark acrizin pigments, tissue mast cell granules do not deliver and disperse, and dyed in different gradation from that of other cells-(While mast cells are dyed dark yellowish brown, the other cells are dyed light yellow. But when they are soaked in israbin solution and acrinol solution-both acrizin pigments-for long years, the difference of the colour tone between them becomes diminished gradually, so this phenomenon cannot be named metachromasia)-and its granules hold a granular shape and are stable, so they are detectable very well.

$\mathrm{Holmgren}$ and Wilander detected the quantity of the mast cell granules within the tissue according to the gradation of colour tone, but as the granules show distinct granular shapes when israbin solution and acrinol solution are used. It is found to be very convinient to detect them quantitatively.

So, from the standpoint of not only fixing but the quantitative detection, the method by acrizin pigment-solutions in far more stable, compared with the method by basic lead acetate solution-opined by Holmgren and Wilander (1937)-or the method by the various fixative-used by me in the above-mentioned experiments and from the stand point of fixing, too, the good result can be obtained. And from the standpoint of staining, too, this method is superior to others.

Concerning the dispersed image of the tissue mast cell Hollander opines that while the delivered and dispersed image of the cell granules can not be found in the case of supravital staining, the dispersed figure can be found in the case of fixative section being used and that this is owing to the mechanical action by microtome.

Y a mada (1931) observed the dispersed image of granules in fixing and staining of the mesentery of rats without using microtome. 
In making the fixative section preparation of subcutaneous connective tissue mast cell of a white mouse according to the ordinary method. I used microtome to cut the paraffin section with, but when it was fixed and stained by acrizin pigment-solution the dispersed image of the granules of tissue mast cell could not be found.

And in the mesentery spread preparation, too, I could not observe the dispersed image of granules except only the parts which seems to be produced artificially.

Judging from the experiment, it is proper to conclude, as Maxi m ow (1906), Tsuda (1923) or Le h ne r (1924) does that the dispersed figure of the granules produced is only due to the mechanical stimulator of the artificial product.

It can be concluded, as the result of this experiment that the dispersed figure of the granules can take place not only owing to the artificial way but also as the rssult of the deposited reaction of cell body.

The deposited reaction of protoplasm was observed of the vegetable protoplasm, for the first time, by Pring and Sheim (1854), $\mathrm{Nag}$ e li and $\mathrm{Cramer}$ (1855), then applied to the measurment of osmotic pressure of the cell and afterwards, of the animal protoplasm, this phenomenon has been studied especially of the blood-corpuscle, and granually, this phenomenon has come to be studied windely in the various fields - not merely in the blood-corpuscle field but also in the hydrogen ion density or chemical or bacteriological field or other.

And thus on various cells "The Micell Doctorine" has come to be advanced : namely, judging from the fact that the ground substance or protoplasm of dispersed system shows its peculiar stability such as preservability, elasticity, turgescence of simple form, while containing a large quantity of water, micells are correlated to each other and form a kind of support system-reticular dispersed system, as it were.

In short, the dissolving protoplasm of tissue mast cell is hard to be observed in the fresh tissue but as it has granules in it, the process in dissolving of cell body is sure to be easily guessed by observing the dispersed figure of granules seen of the stained preparations in various fixatives.

\section{Conclusion}

Using the back subcutaneous connective tissue of the normal white mouse, on the basis of the outline of tissue mast cell body in various 
fixatives, the comparative experiment on the reaction, esp. the stained condition i.e. the change of metachromasia and the resistability, i.e. the dissolved dispersed condition are tried, and for this purpose 15 kinds of fixatives are chosen.

1. The experiment demonetrated that tissue mast cell shows each, different phenomena according to the kinds of fixative, so, in the study of the cell it is necessary to make clear of the reactions of the cell in the fixatives.

When acrizin-pigment solution of various fixatives is used, the granule of this cell shows much stability chemically. Accordingly, the dissolving of the cell body and the delibered and dispersed of granules cannot be observed, but this cannot be called metachromasia.

When this pigment is used, to our great advantage, the staining and fixing are to be done at the same time and thus the satisfactory result can be obtained.

2. This cell, being basophile, seems to dissolve and damage itself in the strong acid fixatives and this reaction of the cell is the same with in the potassium dichromate solution and osmic acid solutionboth, oxidizing agents, but to the alcohol solution and formalin solutionboth, reducing agents, - this cell is comparatively stable and seldom dissolves and damages themselves.

Namely, basophiles cells such as this cell are unstable to the strong acid fixatives or oxidizing agent fixatives.

3. As for the dissolving of tissue mast cell there are two different kinds of type: as ane type, cell membrane is destroyed at first, and the granules are dissolved, and as the other type, protoplasm dissolves earlier than the destruction of the cell membrane.

\section{References}

1) Cas s, R., J. F. Rile y, G. B. We st, K. W. H e a d and S. W. Stroud, 1954. Heparin and histamine in mast cell tumors from dogs. Nature, 174: 318.

2) Ehrlich, P. 1877. Bıiträge zur Kenntniss der Anilinfärbungen und ihrer Verwendung in der mikroscopischen Technik. Arch. Mikr. Anat., 13: 263.

3) E h r l i c h, P. 1879. Beiträge zur Kenntniss der granulierten Bindegewebszellen und eosinophilen Leukozyten. Arch. Physiol., 3: 571.

4) Holmgre n, H. u. Wi l a nde r, O. 1937. Beitrag zur Kenntniss der Chemie und Funktion der Ehrlichen Mastżellen. Z. mikrosk. Anat. Forsch., 42: 242.

5) I man ishi, K. 1937. Experimental study of tissue mast cells in oral organ of normal rat. Shikageppo, 17: 1 .

6) Jorpes, E. and Bergstrom, S. 1937. Heparin: A mucoitin polysulfuric acid. J. Biol. Chem., 118: 477. 
7) K i t a y a ma, Y. 1942. The proof of tissue mast cell granules by trypaflavin. Igakutoseibutsugaku, i : 248 .

8) Lis on, L.A. 1936. Histochemie animale methodes et problems. Gauthier Villars. Paris.

9) Lehner, J. 1924. Das Mastzellen-problem und Metachromasie-Frag. Erg. Anat., 25: 67 .

10) Maximow, A. 1906. Uber die Zellformen des lockeren Bindegewebs. Arch. mikrosk. Anat., $67: 680$.

11) Michaelis, L. 1938. The mast cells in Handbook of Hematology edited by Downey, Vol. 1. New York: PB Hoeber, Inc. 231.

12) Mi u ra, N. (a). 1932. The comparative study of tissue mast cells of various kinds of animals. Tohoku J., 14: 1.

13) Mi ura, N. (b). 1932. The comparative study of tissue mast cells of various kinds of animals. Tohoku J., $14: 65$.

14) $\mathrm{Nakajo}, \mathrm{S} .1927$ 1928. On tissue mast cell. Nisshinigaku, 17: 457.

15) $\mathrm{Nakaji} \mathrm{ma}, \mathrm{Y}$. 1928. The study of tissue mast cell. Jikkenigaku, 12: 341 .

16) Rile y, J.F. 1953. Effect of histamine liberators on the mast cell of the rat. J. Path. Bact., 65 : 471.

17) Riley, J. F. and W e st, G. B. 1956. Mast cells and histamine in normal and pathological tissues. J. physiol., 119: 44.

18) Ri l e y, J. F. and W e s t, G. B. 1953. Presence of histamine in tissue mast-cells. J. Physiol., 12]: 528 .

19) Uraga mi, T. 1940. Physicochemical study of tissue staining. J. Japanese bac. and path., $34: 1$.

20) Unna, P. G. 1911. Die Reduktionsorte und Sauerstofforte des tierischen Gewebes. Zeitschr. Wiss, mikrs., Bd. 8.

21) W a lde y e r, W. 1875. Ueber Bindegewebszellen. Arch. f. mikrs. Anat., 11: 1.

22) $\mathrm{Yam}$ a da, K. 1934. Effect of $\mathrm{PH}$ on the fixative of mast cells. Osaka medical J., $33: 4319$.

\section{The Explanations of Plate Figures}

Fig. 1. Mast cells of mouses back subcutaneous connective tissue in $1 / 20 \mathrm{M}$ israbin aqueous solution are found. A thin membranous specimen. $\times 1000$

Fig. 2. Mast cells in $50 \%$ alcohol solution in which israbin at the rate of $1 / 50 \mathrm{M}$ are found. $\times 1000$

Fig. 3. Mast cells in $1 / 20 \mathrm{M}$ acrinol aqueous solution are found. $\times 1000$

Fig. 4. Mast cells in $5 \%$ alcohol in which acrinol is soluted at the rate of $1 / 50 \mathrm{M}$ are found. $\times 1000$

Fig. 5. Mast cells in $4 \%$ basic lead acetate aqueous solution are found. $1 \%$ toluidin blue staining. $\times 1000$

Fig. 6. Mast cells in absolute alcohol solution are found. $\times 1000$

Fig. 7. Mast cells in $10 \%$ formalin solution are found. $\times 1000$

Fig. 8. Mast cells in $4 \%$ formalin solution are found. $\times 1000$

Fig. 9. Mast cells in neutral formalin solution are found. $\times 1000$

Fig. 10. Mast cells in Zenker's solution is found. $\times 1000$

Fig. 11. Mast cells in müller's solution are found. $\times 1000$

Fig. 12. Mast cells in $1 \%$ osmic acid solution are found. $\times 1000$ 
Plate I
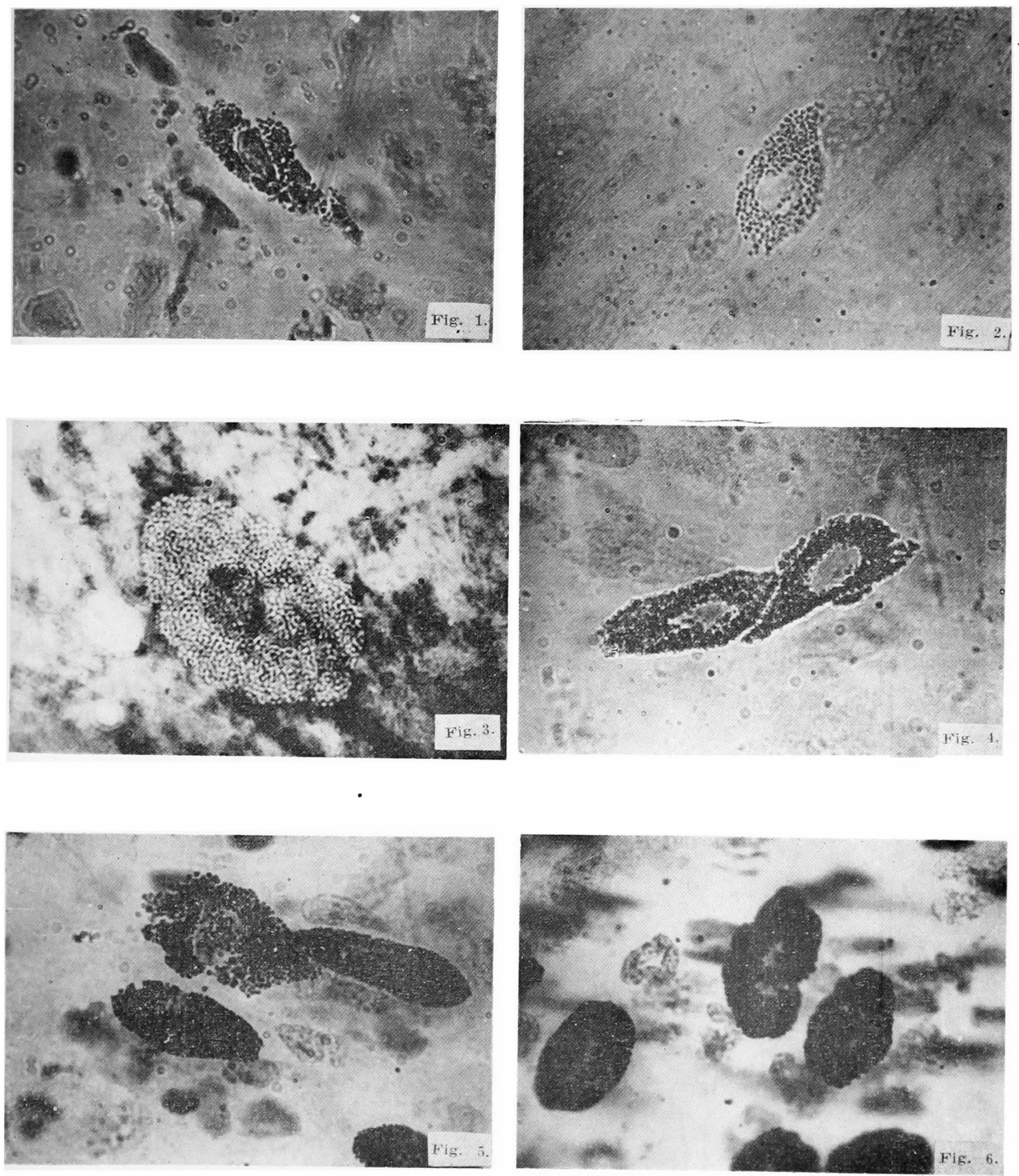

Yoshınori Takeda 
Plate II
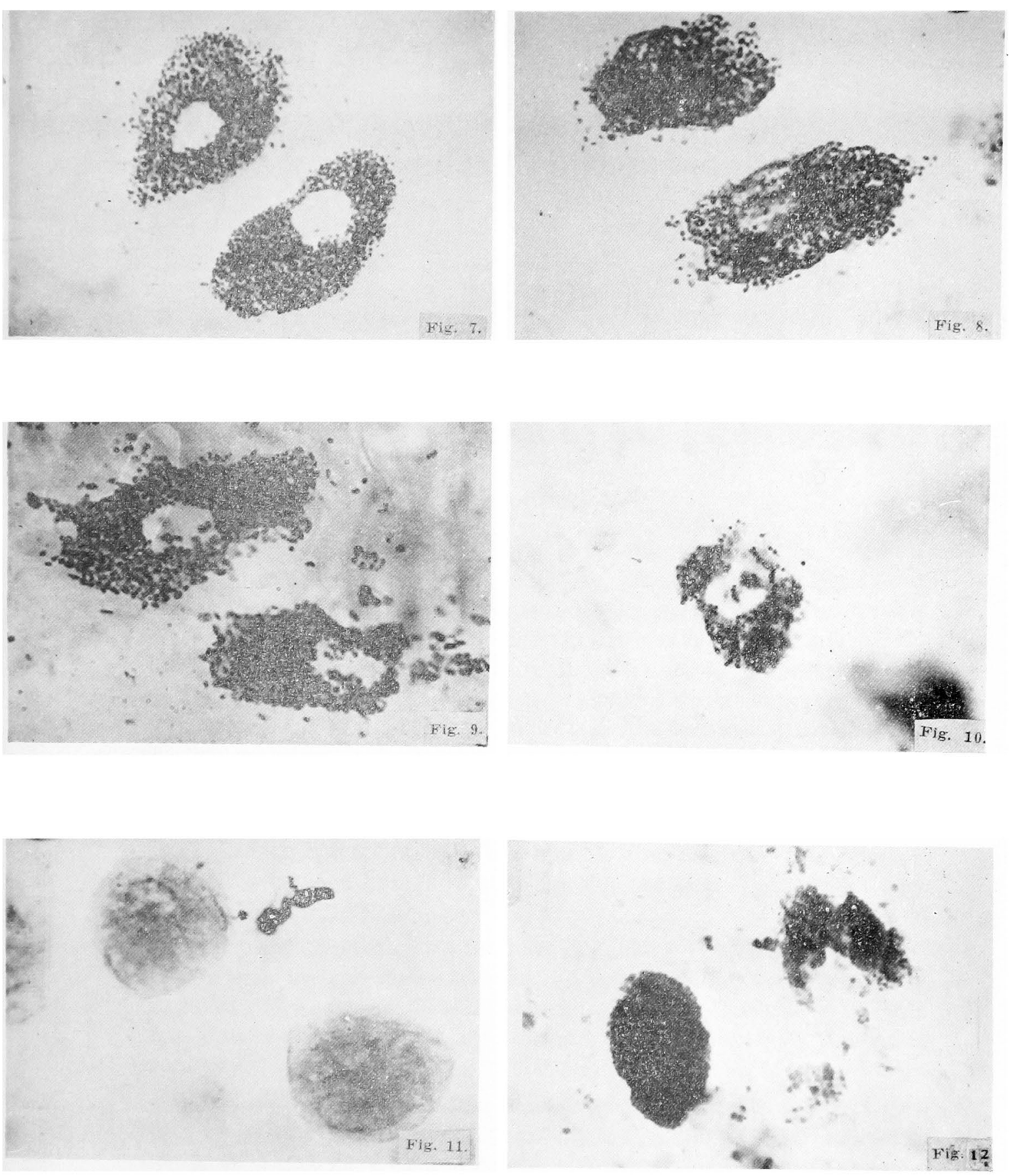

Yoshinori Takeda 